DOI: 10.24125/sanamed.v13i3.265

UDK: 616.94:314.153.3-054.73(560)"2018"

\title{
SCREENING FOR HEPATITIS B AND C SEROPREVALENCE AND PREVALENCE OF HIV INFECTION AMONG AFGHAN REFUGEES NEWLY ARRIVED IN COASTAL REGION TURKEY IN 2018: A SYSTEMATIC SINGLE-CENTRE ANALYSIS
}

\author{
Ayvaz Ali Muhammed, ${ }^{1}$ Turfan Selim, ${ }^{2}$ Kesicioğlu Tuğrul, ${ }^{3}$ Dülger Cumhur Ahmet, ${ }^{1}$ \\ Ayraler Arzu, ${ }^{4}$ Vural Abdussamed, ${ }^{2}$ Dikbaş Oğuz ${ }^{5}$ \\ ${ }^{1}$ Giresun Üniversitesi Prof. Dr İlhan Özdemir Training and Research Hospital, \\ Gastroenterology and Hepatology, Turkey \\ ${ }^{2}$ Giresun Üniversitesi Prof. Dr İlhan Özdemir Training and Research Hospital, Emergency Medicine, Turkey \\ ${ }^{3}$ Giresun Üniversitesi Prof. Dr İlhan Özdemir Training and Research Hospital, General Surgery, Turkey \\ ${ }^{4}$ Giresun Üniversitesi Prof. Dr İlhan Özdemir Training and Research Hospital, Family Medicine, Turkey \\ ${ }^{5}$ Giresun Üniversitesi Prof. Dr İlhan Özdemir Training and Research Hospital, Endocrinology, Turkey
}

Primljen/Received 08. 09. 2018. god.

Abstract: Introduction: Previous studies showed that refugee status have been associated with various deteriorated effects on human health including higher prevalence of hepatitis B, C and HIV infections. In this study we aim to bridge the gap between Afghan immigrants and naive Turkish population by identifying $\mathrm{HBV}, \mathrm{HCV}$ and HIV profiles. In addition, a large number of laboratory parameters was collected for all participants, including hematologic and biochemical test results.

Materials and Methods: We performed a retrospective review of laboratory records at a tertiary center in Northern Turkey from January 1, 2018, to April 15,2018 . Our population based study comprising hospital data of 403 Afghan refugees and 400 naive Turkish citizens. Results: Afghan refugees had higher anti-HIV seropositivity than Turkish citizens $(\mathrm{p}<0.05)$. There were no difference between the two groups according to HbsAg and anti-HCV seropositivity. Also Afghan refugees had statistically lower ALT levels, higher hemoglobin levels and higher mean TSH level $(p<0.05)$. Mean T4 level did not show significant difference between the two groups.

Conclusion: We need further investigations to find out the risk of infections that originated from immigration.

Key words: Immigrants, Infectious diseases, Viral Hepatitis, AIDS.
Prihvaćen/Accepted 12. 11. 2018. god.

\section{INTRODUCTION}

Hepatitis B virus (HBV) infection, hepatitis C virus (HCV) infection and Human immune deficiency virus (HIV) infection are among the top ten causes of infectious disease-related mortality globally (1).

On the other hand, infection with HBV, HCV and HIV continue to be significant causes of morbidity and mortality all over the world and are endemic in South East Asia including Afghanistan (2). Recent reports showed that these increasing trends on that viruses have been attributed to increased traditional opioid use, civil war, and the displaced Afghans into another countries where refugee camps are overcrowded (3).

HBV infection has a high $(\geq 8 \%)$ or intermediate $(2-7 \%)$ prevalence in approximately many parts of Asia (4). In Afghanistan, the prevalence of HBV infection has been estimated as high as $8.3 \%$ (5).

Low prevalence of HIV (0.063\%) and HCV $(0.82 \%)$ has been detected among Afghan National Army (ANA) recruits (6). However it has been also reported that there was a huge increase for both $\mathrm{HCV}$ and HIV infections (3.8\% and $4.6 \%$ respectively) among male injecting drug users in Kabul, Afghanistan (7). However, limited data exist to indicate health parameters involving hepatotrophic viruses for Afghans. To address this data gap, we conducted a study among Afghan refugees newly entering the Turkey. We also compared Afghans to naive Turkish citizens. 


\section{MATHERIALS AND METHODS}

Giresun Hospital, University of Medical Sciences, TR, Turkey

Giresun Hospital is a 500 bed tertiary care hospital, affiliated with Giresun University of Medical Sciences, Giresun, Turkey, which also serves as an urban general hospital in Giresun. It serves as a referral hospital in the area with about 1 million inhabitants in coastal region of Northern Turkey.

\section{Study design}

We performed a cross sectional sociodemographic and laboratory survey among Afghan refugees living in Giresun city (near the coast of eastern Black sea) in Turkey. All Afghan refugees between 2017 and 2018 in the Giresun city were identified using the hospital data system.

\section{Study population}

Refugees (403 subjects) that met the following inclusion criteria were eligible to participate in the study: (i) aged above than 18 years, (ii) originating from Afghanistan, and (iii) living in a reception center in the Turkey. A total of 400 healthy Turkish controls were also enrolled in the final analysis.

\section{Serological analysis}

Hepatitis B (markers: HBsAg and antiHBs) serology was performed using chemoluminescence assays performed on the ADVIA Centaur XP assay system (Siemens HBsAg II assay, HBcT, aHBs2, AHAVT). Anti-HBc positivity with presence of $\mathrm{HBsAg}$ indicates a chronic infection.

$\mathrm{HCV}$ positivity was defined as having newly reactive $\mathrm{HCV}$ antibody ( $\mathrm{HCV} \mathrm{Ab}$ ) by a rapid diagnostic test (RDT) confirmed by either detectable HCV viremia or HCV Ab. HIV positivity was defined as confirmed HIV-1 antibody. Plasma HCV RNA was quantified for each sample with the use of the COBAS Ampli$\mathrm{prep} /$ TaqMan real-time reverse-transcriptase polymerase-chain-reaction assay, version 2.0 (Roche Molecular Diagnostics), which has a lower limit of quantification of $15 \mathrm{IU}$ per milliliter. HIV infection was defined as positive test result with the use of a third-generation HIV enzyme immunoassay (VITROS Anti-HIV 1+2 Assay, Ortho Clinical Diagnostics).

\section{Laboratory Analysis}

Hematologic and biochemical studies were conducted via automatic analyzer with SYSMEX XN 1000 (Sysmex Coorporation - Kobe, Japan). Serum thyroxine and thyrotropin were measured with use of an automated immunoassay with chemiluminescence detection Roche Cobas 8000 modular analyzer (Roche Diagnostics GmbH, Mannheim, Germany) and commercial reagents.

\section{Statistical Analysis}

Analyses were conducted with the use of SAS software, version 9.2 (SAS Institute), and R software, version 2.15.1 (R Project for Statistical Computing). We used the chi-square test and Pearson correlation tests test to compare demographic variables and laboratory parameters between study groups. $\mathrm{P}$ values of less than 0.05 were considered to indicate statistical significance.

\section{RESULTS}

The median age of the Afghan refugees was 34 years (interquartile range, 18 to 65 ), $58 \%$ were men, and all of them resided in Giresun city. Median age of control subjects was 36 years (ranged from 17-78). Control group (400 subjects; 200 of them were women) were selected from healthy Turkish subjects from Giresun city. There was no statistically significant difference between groups in terms of age and gender (all $\mathrm{P}>0.05$ ).

A total of $2.8 \%$ (11 patients; 7 female) of control subjects tested positive for HBs antigen. Other hand, $5.8 \%$ (23 subjects; 13 female) of 403 refugees had seropositive for HBs antigen as shown in Table 1. There was no significant difference between the refugee group and the Turkish control group with respect to the overall prevalence of $\mathrm{HBV}$ infection $(\mathrm{P}=0.106)$.

On study entry, $1.2 \%$ of control subjects (5 subjects; 3 of them were female) had seropositive for anti-HCV antibody. Among Afghan refugees, $2.3 \%$ of subjects ( 9 patients; 5 of them were female) tested positive for both anti- HCV antibody and HCV RNA. There was no significant difference between the refugee group and the Turkish group in the mean percentage of subjects who had seropositive results for anti-HCV antibody $(\mathrm{P}=0.403)$.

Table 1. Seroprevalance of $H B V, H C V, H I V$

\begin{tabular}{|l|c|c|c|}
\hline & HBsAg & Anti-HCV/HCV RNA & HIV-RNA \\
\hline Giresun Citizens (200 male-200 female) & $11(7$ female $)$ & $5(3$ female $)$ & 0 \\
\hline Afghan Refugees (233 male-170 female) & 23 (13 female $)$ & $9(5$ female $)$ & $9(6$ female, 3 male $)$ \\
\hline
\end{tabular}


A total of 803 study subjects screened for anti-HIV antibody. At the end of analysis, no control subjects tested positive for HIV infection who selected from Turkish citizens resided in the Giresun city. Other hand, 9 refugees $(2.3 \%)$ had positive test results for both anti-HIV antibody and HIV- RNA. HIV viral-load assays were also performed in all patients. There was significant difference between two groups in the percentage of subjects with HIV infection $(\mathrm{P}=0.005)$.

The mean serum TSH level was higher in refugees than in control subjects $(3.5 \pm 10.8$ versus $2.1 \pm 1.7 \mu \mathrm{g}$ per deciliter, $\mathrm{P}=0.019$ ) When age and sex were controlled for in a multivariate analysis, elderly ages were associated with a lower levels of TSH but gender status was not. In addition, the mean serum T4 level was not statistically significant between Afghans and Turks (1.18 \pm 0.77 versus $1.13 \pm 0.33 \mu \mathrm{g}$ per deciliter, $\mathrm{P}=0.31$ ).

Other laboratory test results of Afghan refugees showed significantly lower serum ALT levels and increased hemoglobin levels in comparison to healthy
Turkish controls $(19 \pm 12$ versus $22 \pm 24$ unit per liter, $\mathrm{P}$ $=0.018 ; 13.9 \pm 1.8$ versus $12.8 \pm 1.9$ gram per deciliter, $\mathrm{P}=0.001)$. Baseline characteristics of the study subjects showed in the Table 2 .

\section{DISCUSSION}

The results of this population based study showed that the prevalence of HIV infection was higher than those naive Turkish population at the coast of Black sea. We also demonstrated a positive correlation between HCV and HIV infections particularly among afghan refugee women. Furthermore, we also detected higher TSH levels in Afghan refugees than those Turkish counterparts. Interestingly, both of $\mathrm{HBV}$ and $\mathrm{HCV}$ infection prevalence of Afghan immigrants were similar to Turkish subjects.

HBV infection is associated with cirrhosis and hepatocellular carcinoma. Although preventive efforts can reduce the incidence of HBV infection, refugees

Table 2. The results for the two groups according to biochemical parameters

\begin{tabular}{|c|c|c|c|c|c|c|}
\hline & & $\mathrm{N}$ & Mean & Std. Dev. & Min. & Max. \\
\hline \multirow{3}{*}{$\begin{array}{l}\mathrm{Hgb} \\
\mathrm{g} / \mathrm{dl}\end{array}$} & Giresun citizens & 400 & 12,8915 & 1,91556 & 7,80 & 17,60 \\
\hline & Afghan refugees & 403 & 13,9404 & 1,85452 & 8,00 & 19,00 \\
\hline & Total & 803 & 13,4179 & 1,95573 & 7,80 & 19,00 \\
\hline \multirow{3}{*}{$\begin{array}{l}\text { Glukoz } \\
\text { mg/dl }\end{array}$} & Giresun citizens & 363 & 111,43 & 45,353 & 11 & 427 \\
\hline & Afghan refugees & 305 & 105,82 & 41,339 & 11 & 401 \\
\hline & Total & 668 & 108,87 & 43,624 & 11 & 427 \\
\hline \multirow{3}{*}{$\begin{array}{l}\mathrm{AST} \\
\mathrm{U} / \mathrm{L}\end{array}$} & Giresun citizens & 358 & 23,16 & 15,747 & 10 & 146 \\
\hline & Afghan refugees & 324 & 22,38 & 10,182 & 10 & 93 \\
\hline & Total & 682 & 22,79 & 13,391 & 10 & 146 \\
\hline \multirow{3}{*}{$\begin{array}{l}\text { ALT } \\
\mathrm{U} / \mathrm{L}\end{array}$} & Giresun citizens & 360 & 22,87 & 24,151 & 4 & 255 \\
\hline & Afghan refugees & 329 & 19,33 & 12,627 & 4 & 103 \\
\hline & Total & 689 & 21,18 & 19,583 & 4 & 255 \\
\hline \multirow{3}{*}{$\begin{array}{l}\text { Albumin } \\
\mathrm{g} / \mathrm{dl}\end{array}$} & Giresun citizens & 82 & 4,3530 & ,53092 & 2,80 & 5,10 \\
\hline & Afghan refugees & 101 & 4,4175 & 85999 &, 59 & 5,30 \\
\hline & Total & 183 & 4,3886 & ,72996 & ,59 & 5,30 \\
\hline \multirow{3}{*}{$\begin{array}{c}\text { Kreatinin } \\
\mathrm{mg} / \mathrm{dl}\end{array}$} & Giresun citizens & 360 & 1,1808 & 6,15795 & ,34 & 117,00 \\
\hline & Afghan refugees & 331 &, 8300 & 1,40057 & ,30 & 26,00 \\
\hline & Total & 691 & 1,0128 & 4,54956 & ,30 & 117,00 \\
\hline \multirow{3}{*}{$\begin{array}{c}\mathrm{T} 4 \\
\mathrm{ng} / \mathrm{dl}\end{array}$} & Giresun citizens & 297 & 1,1334 & ,33771 & 1,00 & 3,00 \\
\hline & Afghan refugees & 139 & 1,1871 & ,77617 &, 00 & 9,00 \\
\hline & Total & 436 & 1,1505 & 51899 &, 00 & 9,00 \\
\hline \multirow{3}{*}{$\begin{array}{c}\mathrm{TSH} \\
\mu \mathrm{U} / \mathrm{ml}\end{array}$} & Giresun citizens & 324 & 2,1052 & 1,77161 &, 01 & 15,81 \\
\hline & Afghan refugees & 181 & 3,5508 & 10,82126 & ,01 & 100,00 \\
\hline & Total & 505 & 2,6233 & 6,65689 & 01 & 100,00 \\
\hline
\end{tabular}


have still a key role for disease transmission, not only in Western countries but also in developing world. Thus, the prevention of HBV transmission is the most effective way to reduce the global burden of HBV infection particularly among refugees (8). A previous study from northern part of Turkey reported that overall Hbsag prevalence was $4 \%$. The same study showed $4.4 \% \mathrm{HBsAg}$ prevalence with male group, $3.6 \%$ with female group and there was significant gender difference between the two groups (9). Despite available preventive approaches, refugees often experience symptoms and complications of communicable diseases such as HBV infection. A study from Pakistan reported that seroprevalence of HBs Ag among Afghan refugees living in the camps was $8.3 \%$ (5). While the study among refugees arriving from Afghanistan into the Pakistan, found a seroprevalence as high as $10.1 \%$ (10). Focusing on the link between the Afghan immigration and HBV infection we tested subjects for presence of HBs seropositivity. At the final analysis, there had no significant difference between groups in terms of the seroprevalence of HBs antigen. Lower seroprevalence of $\mathrm{HBV}$ infection may have been due to higher socioeconomic status of the refugees.

We also investigated the prevalence of $\mathrm{HCV}$ infection profiles of Afghan refugees and their healthy counterparts to study whether the risk of HCV infection was higher among refugees or not. Hepatitis $\mathrm{C}$ virus $(\mathrm{HCV})$ is one of the most common hepatotrophic infections and the predominant risk factors for $\mathrm{HCV}$ acquisition are injection-drug use; blood transfusion before 1992, high lifetime number of sexual partners, and iatrogenic transmission, including through dialysis (11). The seroprevalence of HCV has reportedly been as $0-1 \%$ in Turkey and $1-2 \%$ in Afghanistan $(12,13)$.

In our study, the seroprevalence of anti-HCV in Afghan refugees was determined to be similar to Turkish citizens. Providing evidence of high similarity with other studies $(10,14)$. We showed that seroprevalence of HBV and HCV among Afghan refugees was found to be similar to those in Turkish citizens; however, HIV infection was more frequent than Turkish counterparts.

Turkish community have also historically a very low prevalence of human immunodeficiency virus (HIV) infection due to traditional rules. In studies conducted in Turkey, the seroprevalence of anti-HIV has been established as $1 \%$ in the $0-18$ years range. According to the recent studies, there were 13,181 HIV-positive patients in Turkey in 2016, and broadly 2500 new cases are diagnosed annually in the country (15).

Two previous studies also addressed HIV prevalence among Afghan refugees attending primary care clinics in Pakistan and reported HIV rates in individuals from Afghanistan of as high as $6 \%(10,16)$.
Other research from Afghanistan showed that the prevalence of HIV infection was as low as $0.063 \%$, but this study conducted among younger Afghan army soldiers (6).

Higher prevalence of HIV infection were probably a result of conditions related to refugee status including lack of infrastructure, overcrowded camps, insufficient health care systems and low economic income, although increased sexual activity among refugees may also have contributed. Although the effectiveness of prevention efforts for HIV infection remains uncertain, our findings are crucial to understanding whether the current evidence-based interventions are sufficient to reduce HIV infection and to guide screening refugees. Additionally, these findings prompt the need for prospective investigation into the potential benefit of spreading HIV infection among Afghan refugees.

Iodine deficiency is well known and important reason for goiter. It is also shown that iodine deficiency results in mild TSH elevation and reduction in thyroid hormone serum levels. Iodine deficiency was seen more in cases with hypothyroidism, while excess of iodine was observed to be more frequent in hyperthyroid patients (17). Iodine replacement program in some countries was shown to be reduction of mean TSH value of the people (18). Other hand, endemic goiter is now the most common type of thyroid disease diagnosed in Afghanistan. In the current study, the higher levels of TSH in immigrants from Afghanistan were probably due to their geographic localization. That means it is close to Himalaya mountain region well known iodine deficient mountain area (19). On the other side Giresun is a coastal province to the Black Sea. People here consumes iodinated sea food and also last decade's iodination programs of the food is well done.

The most common liver diseases are nonalcoholic fatty liver disease (NAFLD), alcoholic liver disease, and viral hepatitis among the population. Elevated liver enzymes levels (mainly ALT) are positively associated with the prevalence of NAFLD (20). For patients suspected to have NAFLD because of elevated liver enzymes transabdominal ultrasound may confirm the presence of hepatosteatosis (21).

In the current study, the mean liver transaminase levels of refugees was lower than Turkish citizens, which suggests that prevalence of NAFLD substantially low among Afghans.

This study has several limitations. First, individual data, marital status, location of born places, both of illicit and intravenous drug use and sexual behaviors were not reported by the participants and may be subject to social desirability and other biases. Second, due to retrospective nature of the study we did not perform radiologic techniques to show hepatobiliary system 
and thyroid tissue. Furthermore, an important consideration is whether our estimates of prevalence of $\mathrm{HBV}$, $\mathrm{HCV}$ and HIV infections can be generalized entire the Afghan population.

Higher rates of HIV infection may have been associated with infrastructure of refugee camps and health care systems of residential areas of refugees in Afghanistan. Unexpected higher rates in the incidence of HIV infection indicate a need to strengthen prevention efforts to treat immigrant women, including improvement health care systems as well as long-term surveillance programs. There will be also unmeasured indirect costs, including loss of socioeconomic support for both refugee women and their families inside the traditional Turkish town. Moreover, our comprehensive analysis identified several targets for refugee trials. Additional studies are needed to further define the characteristic features of Afghans.

\section{CONCLUSION}

Immigration may lead to spread of some infections especially HBV, HCV, and HIV. We need further investigations to find out the risk of infections that originated from immigration.
Abbreviations
HBV - Hepatitis B virüs infection
HCV - Hepatitis C virüs infection
HIV - Human immunodeficiency virus
HBsAg - Hepatitis B surface antigen
Anti HBs - Hepatitis B surface antibody
AntiHBc - Hepatitis B core antibody
TSH - Thyroid stimulating hormone
NAFLD - Nonalcoholic fatty liver disease
AIDS - Acquired immune deficiency syndrome
ALT - Alanine aminotransferase
RNA - Ribonucleic acid

\section{DECLARATION OF INTEREST}

The autors declare that there are no conflicts of interests.

\section{Licensing}

This work is licensed under a Creative Commons Attribution 4.0 International (CC BY 4.0) License.

\title{
Sažetak
}

\section{SKRINING ZA HEPATITIS B I C SEROPREVALENCU I PREVALENCA HIV INFEKCIJE MEĐU AVGANISTANSKIM IZBEGLICAMA KOJE SU 2018. GODINE STIGLE U OBALSKO PODRUČJE TURSKE: SISTEMATSKA ANALIZA}

\author{
Ayvaz Ali Muhammed, ${ }^{1}$ Turfan Selim, ${ }^{2}$ Kesicioğlu Tuğrul, ${ }^{3}$ Dülger Cumhur Ahmet, ${ }^{1}$ \\ Ayraler Arzu, ${ }^{4}$ Vural Abdussamed, ${ }^{2}$ Dikbaş Oğuz ${ }^{5}$ \\ ${ }^{1}$ Giresun Üniversitesi Prof. Dr İlhan Özdemir Training and Research Hospital, Gastroenterology and Hepatology, Turkey \\ ${ }^{2}$ Giresun Üniversitesi Prof. Dr İlhan Özdemir Training and Research Hospital, Emergency Medicine, Turkey \\ ${ }^{3}$ Giresun Üniversitesi Prof. Dr İlhan Özdemir Training and Research Hospital, General Surgery, Turkey \\ ${ }^{4}$ Giresun Üniversitesi Prof. Dr İlhan Özdemir Training and Research Hospital, Family Medicine, Turkey \\ ${ }^{5}$ Giresun Üniversitesi Prof.Dr İlhan Özdemir Training and Research Hospital, Endocrinology, Turkey
}

Uvod: Prethodne studije su pokazale da je status izbeglice povezan sa različitim pogoršanim efektima na ljudsko zdravlje uključujući veću rasprostranjenost hepatitis B, C I HIV infekcija. U ovoj studiji naš je cilj da premostimo jaz između avganistanskih imigranata $\mathrm{i}$ turske populacije time što ćemo identifikovati HBV, HCV I HIV profile. Pored toga, prikupljen je veliki broj laboratorijskih parametara za sve učesnike, uključujući rezultate hematološkog i biohemijskog testa. Materijali i metode: Izvršili smo retrospektivni pregled laboratorijskih evidencija u tercijarnom centru u severnoj Turskoj od 1. Januara 2018. godine do 15. Aprila 2018. godine. Naša studija populacije zasnova- na je na bolničkim podacima od 403 avganistanske izbeglice i 400 turskih građana.

Rezultati: Izbeglice iz Avganistana su imale veću anti-HIV seropozitivnost od turskih građana $(\mathrm{p}<0.05)$. Nije bilo razlike između dve grupe prema $\mathrm{HbsAg}$ i anti-HCV seropozitivnosti. Takođe, avganistanske izbelice su imali statistički niže nivoe ALT, veće nivoe hemoglobina i viši srednji TSH nivo $(p<0.05)$. Srednja vrednost T4 nije pokazala značajnu razliku između ove dve grupe.

Zaključak: Potrebna su nam dodatna istraživanja ne bi li pronašli rizike infekcija koji potiču od imigracije.

Ključne reči: Imigranti, infektivne bolesti, virusni hepatitis, AIDS. 


\section{REFERENCES}

1. Lozano R, Naghavi M, Foreman K, Lim S, Shibuya K, Aboyans $\mathrm{V}$ et al. Global and regional mortality from 235 causes of death for 20 age groups in 1990 and 2010: a systematic analysis for the Global Burden of Disease Study 2010. Lancet. 2012; 380(9859): 2095-128.

2. World Health Organization . Global distribution of hepatitis A, B and C. Weekly Epidemiological Record.: WHO; 2002.

3. Stempel C, Sami N, Koga PM, Alemi Q, Smith V, Shirazi A. Gendered Sources of Distress and Resilience among Afghan Refugees in Northern California: A Cross-Sectional Study. Int J Environ Res Public Health. 2016; 14(1): E25.

4. Shepard CW1, Simard EP, Finelli L, Fiore AE, Bell BP. Hepatitis B virus infection: epidemiology and vaccination. Epidemiol Rev. 2006; 28: 112-25.

5. Quddus A, Luby SP, Jamal Z, Jafar T. Prevalence of hepatitis B among Afghan refugees living in Balochistan, Pakistan. Int J Infect Dis. 2006; 10(3): 242-7.

6. Todd CS, Nasir A, Mansoor GF, Sahibzada SM, Jagodzinski LL, Salimi F, et al. Cross-sectional assessment of prevalence and correlates of blood-borne and sexually-transmitted infections among Afghan National Army recruits. BMC Infect Dis. 2012; 12: 196

7. Todd CS, Nasir A, Stanekzai MR, Fiekert K, Rasuli MZ, Vlahov D, et al Prevalence and correlates of HIV, syphilis, and hepatitis $\mathrm{B}$ and $\mathrm{C}$ infection and harm reduction program use among male injecting drug users in Kabul, Afghanistan: A cross-sectional assessment. Harm Reduct J. 2011; 8:22.

8. European Association for the Study of the Liver EASL clinical practice guidelines: management of chronic hepatitis B virus infection. J Hepatol. 2012; 57(1): 167-85.

9. Igde FA, Taskin H,Igde M, Yazici Z, Atilla A. Where we are in the fight against Hepatitis B Infection; Trends in Hepatitis B virus seroprevalence in Black Sea Region of Turke. Niger J Clin Pract. 2018; 21(1): 87-92.

10. Khanani MR, Ansari AS, Khan S, Somani M, Kazmi SU, Ali SH. Concentrated epidemics of HIV, HCV, and HBV among Afghan refugees. J Infect. 2010; 61(5): 434-7.

\section{Correspondence to / Autor za korespondenciju} Selim Turfan

adress: Kavaklar m.Tutkun s. no:3 d:28 Merkez/Giresun Phone: 00905066921719

e-mail: dr.selimturfan@hotmail.com
11. Liang TJ, Ward JW. Hepatitis C in injection-drug users - a hidden danger of the opioid epidemic. N Engl J Med. 2018; 378(13): 1169-71.

12. Kalem F, Yuksekkaya S, Basaranoglu M. The seroprevalence of both hepatitis $B$ and hepatitis $C$ at the first-step health organizations and the difference between the urban and rural areas. Wien Clin Wochenschr. 2016; 128(19-20): 695-9.

13. Todd CS, Nasir A, Stanekzai MR, Fiekert K, Sipsma HL, Vlahov D, et al. Hepatitis $\mathrm{C}$ and HIV incidence and harm reduction program use in a conflict setting: an observational cohort of injecting drug users in Kabul, Afghanistan. Harm Reduct J. 2015; 12:22.

14. Chemaitelly H, Mahmud S, Rahmani AM, Abu-Raddad Lj. The epidemiology of hepatitis C virus in Afghanistan: systematic review and meta-analysis. Int J Infect Dis. 2015; 40: 54-63.

15. Ozdemir B, Yetkin MA, Bastug A, But A, Aslaner H, Akinci E, Bodur H. Evaluation of epidemiological, clinical, and laboratory features and mortality of 144 HIV/AIDS cases in Turkey. HIV Clin Trials. 2018; 19(22): 69-74.

16. RuiseZor-Escudero H, Wirtz AL, Berry M, Mfochive-Njindan I, Paikan F, Yousufi HA, et al. Risky behavior and correlates of HIV and Hepatitis C Virus infection among people who inject drugs in three cities in Afghanistan. Drug Alcohol Depend. 2014; 143: 127-33.

17. Ergür AT, Evliyaoğlu O, Şıklar Z, Bilir P, Öcal G, Berberoğlu M. Evaluation of thyroid functions with respect to iodine status and TRH test in chronic autoimmune thyroiditis. J Clin Res Pediatr Endocrinol. 2011; 3(1): 18-21.

18. Heydarian P, Ordookhani A, Azizi F. Goiter rate, serum thyrotropin, thyroid autoantibodies and urinary iodine concentration in Tehranian adults before and after national salt iodization. J Endocrinol Invest. 2007; 30(5): 404-10.

19. Ramalingaswami V. Endemic goiter in Southeast Asia. New clothes on an old body. Ann Intern Med. 1973; 78(2): 277-83.

20. Liu CF, Zhou WN, Lu Z, Wang XT, Qiu ZH. The associations between liver enzymes and the risk of metabolic syndrome in the elderly. Exp Gerontol. 2018; 106: 132-6.

21. Ferraioli G, Tinelli C, De Silvestri A, Lissandrin R, Above E, Dellafiore $\mathrm{C}$ et al. The clinical value of controlled attenuation parameter for the noninvasive assessment of liver steatosis. Liver Int 2016; 36(12): 1860-6. 